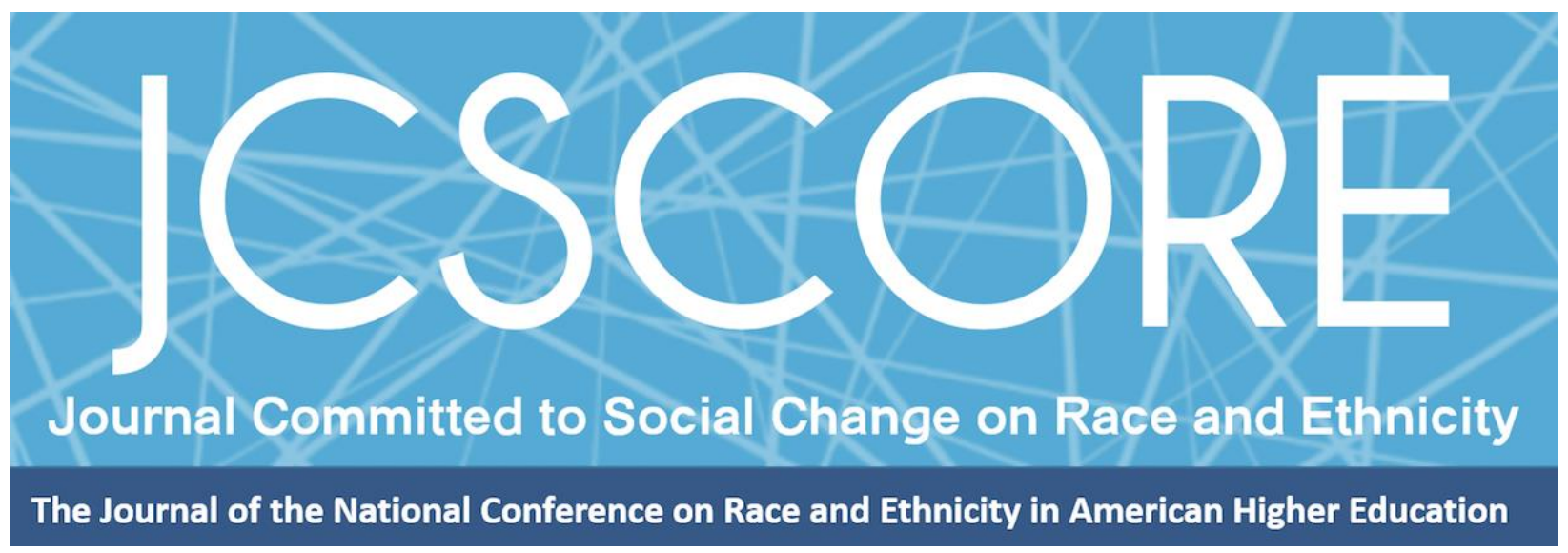

\title{
SO, THIS IS AMERICA?
}

\author{
Rochilda Fevrius \\ Florida Atlantic University
}

\section{Journal Committed to Social Change on Race and Ethnicity Volume 7, Issue 1 | 2021}

\section{Copyright and Open Access}

(c) 2021 Rochilda Fevrius

\section{(c) (i) (2)}

This work is licensed under a Creative Commons Attribution-NonCommercial-ShareAlike 4.0 International License. Permission of the authors is required for distribution and for all derivative works, including compilations and translations. Quoting small sections of text is allowed as long as there is appropriate attribution and the article is used for non-commercial purposes.

The Journal Committed to Social Change on Race and Ethnicity (ISSN 2642-2387) is published by the National Conference on Race and Ethnicity (NCORE), a production of the University of Oklahoma, in partnership with the University of Oklahoma Libraries. 
So, This is America?

Rochilda Fevrius

Florida Atlantic University

In this poem, the author sheds light on the struggles of police brutality, racism, and injustice that rampage through the Black community. The author's poem illustrates the feeling of devastation from the lack of equality and justice for Black individuals in America, who constantly live-in fear. The author is a Black woman, who witnesses and experiences discrimination and unfairness, and questions is this what America really is? She writes this poem in an effort to hold the disruptive systems in America, racist individuals, and brutal police accountable for their damage and destruction of Black people and Black communities. The poem was unfortunately inspired by the killings of innocent Black individuals such as Daunte Wright, Brandon Bernard, Breonna Taylor, George Floyd, Ahmaud Arbery, and the many other Black lives reduced to a hashtag.

So, this is America huh?

Home of the free

Land of the brave

But never the land built on the back of the slaves

Who paved the roads

You so freely commute on?

While we get traffic stopped

Picked and condemned

And only a given a minute

To live in this skin

Does justice have a skin color?

Because mine doesn't get much of it 
This skin tone is condoned

And damn it America I am sick

And tired of this game

Of tag the Black one is always it

Wrapped around the jail cell

Is always the Black men's fist

Duck duck the Black woman

Always gets the hit

Dodgeball I mean bullet

To the Black men's chest

Hopscotch on the Black men's neck

Because somehow, we're always on the list

And you wonder why we're pissed

You silence and put us to death

Like the silencers on your guns

When shoot through our loved ones

But wait you don't even use the silencers

You do it loud and proud

Out in the open

In the midst of a crowd

And always get away with it

As you rip through our flesh but

Why not take the breath and put to death 
A person who took many lives'

Instead of taking mine?

Because being Black in America

Is a death sentence in itself

And all I do is exist in this skin

And that's enough for an electric farewell

A lethality injected execution

When we should be executing

This system

Taking the innocent Black lives

Out of prison

Quit playing the victim

Letting the Black people live

And stop trying to kill them

Well, let me remind you

That one is innocent until proven guilty

And America you have been guilty

Since the slave trade and

Genocide of the indigenous peoples

And here we are still divided

Unequal and still being injected with needles

But I finally get it

You took off the shackles 
Called it freedom

When in reality this is still

Four hundred years the sequel

To your cruelty and evil

In a country where we either get

The whip the chair the pistol

Or paralyzed from the waist down

Marked as a target

Because my shade is brown

And you are amused

Like I'm some sort of stage clown

As you continue to auction the

Black and Brown skin

As you ripple through our life's

And pluck at our heart strings

Like the waves of violin

When you commit the violent crimes

Of your dark sins

It's funny how

You couldn't live nor walk a day in my shoes

You couldn't take the pain of my bruise

Or bare to hear the sound of my blues

Living in a White washed and broken America 
Journal Committed to Social Change on Race and Ethnicity | Volume 7, Issue 1 | 2021

Where the White men is free

While the Blacks pay the dues

America our Freedom is long overdue

And no, you can't undo

The damage already done

So quit treating racism as taboo

And realize that you are the one

That has death sentence stamped

On the Black body like a tattoo

Yes, America that's you! 